\title{
Trends in and Prospects for the Coal Industry Development in Russia's Eastern Regions
}

\author{
L.N. Takaishvili, A.D. Sokolov
}

Melentiev Energy Systems Institute of Siberian Branch of Russian Academy of Sciences, Irkutsk, Russia

\begin{abstract}
The paper presents an analysis of trends in coal industry development in Russia's eastern regions and its significance for the national coal industry. The study focuses on the prospects for the coal industry development in Russia's east and the potential directions of coal use there. The coal production and supplies for export are projected for the period up to 2035 .
\end{abstract}

Index Terms: coal, production, supplies, export, balance reserves, eastern regions of Russia, projects, trends.

\section{INTRODUCTION}

The coal industry of Russia's eastern regions plays a significant part in providing Russia's regions with resources and exporting them. The eastern regions are East Siberia and the Far East. Coal plays a leading role in the energy balance of these regions and is the primary fuel for thermal power plants. The coal industry is of high social significance as a mainstay of the coal-producing entities of the federation.

The coal share in the fuel consumption structure of the federation entities of the eastern regions ranges between $5 \%$ and $95 \%$ and averages $50 \%$. It accounts for $50-60 \%$ in West Siberia and $0-8 \%$ in European Russia. In the retrospective, coal consumption decreased both in the country and in the eastern regions. Coal is consumed in the coal-mining regions of the country. It is supplied to other Russia's regions and for export. The coal share in exports in the eastern direction is growing steadily. For the reasons of the high social and economic significance of the coal industry in Russia's east, the study of its development appears to be of great importance.

\footnotetext{
${ }^{*}$ Corresponding author.

E-mail: luci@isem.irk.ru
}

http://dx.doi.org/10.38028/esr.2020.04.0003

Received November 10, 2020. Revised November 30, 2020.

Accepted December 13, 2020. Available online February 01, 2021.

This is an open access article under a Creative Commons Attribution-NonCommercial 4.0 International License.

(C) 2020 ESI SB RAS and authors. All rights reserved.

\section{CURRENT STATE}

Russia is one of the world leaders in the volumes of coal reserves, production, consumption, and export [1]. The coal industry share of the eastern regions increases and at present is sufficiently high (Table 1). The analysis of the dynamics of coal supplies from the eastern regions revealed a considerable growth of coal supplies for export with the relative stability of supplies to the internal market (Table 2). In the structure of export supplies, in 2011-2018, the European regions of Russia increased the coal supplies by $28 \%$, West and East Siberia approximately twice, and the Far East almost by four times. During this period, coal supplies in the eastern direction increased almost nine times and in the western direction only by $28 \%$ [2]. The growing coal supplies for export in the eastern direction were provided by the enterprises of the eastern regions and West Siberia.

The tendency toward coal production growth was observed primarily in the regions supplying coal for export. Starting in 2010, most of them increased coal production and export almost twice, excluding the Sakhalin region, where coal export increased more than 14 times. In 2019, the share of coal supplied for export made up from 35 to $90 \%$ of production volumes for different regions. Of great significance for the coal industry in the eastern regions is closeness to the trade markets and shorter transportation distances compared to West Siberia. China, Japan, and other APR countries are major coal importers from Russia's eastern regions.

In the internal coal market, coal consumers in the eastern regions are situated basically in the coal production areas and those close to them. Power plants are the major coal consumers in Russia's east. In the considered period, coal supplies for coking purposes in the eastern regions increased against the decrease in coal supplies for coking in the country as a whole.

\section{COAL RESERVES}

The eastern regions of Russia possess considerable balance and non-commercial reserves of steaming and coking coals, including those of deficient ranks (Table 3 ). The share of the eastern regions in the structure of coal reserves accounts for $45 \%$, that of West Siberia is $46 \%$, and of the European part of Russia - 9\% [3]. The available 
Table 1. Coal industry of Russia and its eastern regions (as of 2019)

\begin{tabular}{|c|c|c|}
\hline Indicator & Russia & Eastern regions \\
\hline Balance reserves $(\mathrm{A}+\mathrm{B}+\mathrm{C} 1)$, billion $\mathrm{t}$ & 196.2 & $88.0(44.7 \%)$ \\
\hline The number of enterprises: & 187 & $65(34.8 \%)$ \\
\hline \multicolumn{3}{|l|}{ including } \\
\hline - mines & 57 & $5(8.8 \%)$ \\
\hline - open-pits & 130 & $60(46.2 \%)$ \\
\hline Production capacity, million tons & 541.1 & $218.1(40.3 \%)$ \\
\hline Number of dressing works & 64 & $7(1.9 \%)$ \\
\hline Coal production, million tons & 441.4 & $161.4(36.5 \%)$ \\
\hline -underground mining, million tons & 107.3 & $6.8(6.3 \%)$ \\
\hline -surface mining, million tons & 334.1 & $154.6(46.3 \%)$ \\
\hline Coal processing, million tons & 206.0 & $49.0(23.8 \%)$ \\
\hline Coal import, million tons & 21.1 & $3 / 4$ \\
\hline Coal supply by coal producers, million tons & 373.6 & $141.7(37.9 \%)$ \\
\hline including export, million tons & $\begin{array}{l}206.3^{*} \\
192.3^{* *}\end{array}$ & $47.1(24.5 \%)$ \\
\hline Consumption, million tons (2018) & 233.0 & $91.6(39.3 \%)$ \\
\hline including internal, million tons & 211.9 & 88.2 \\
\hline
\end{tabular}

Source: [2]

* JSC Russian Railways

** CDU TEK

Table 2. Characteristic of the coal industry of Russia's eastern regions, million $t$

\begin{tabular}{|c|c|c|c|c|c|}
\hline \multirow[t]{2}{*}{ Indicator } & \multicolumn{5}{|c|}{ Year } \\
\hline & 2010 & 2015 & 2017 & 2018 & 2019 \\
\hline Production & 111.2 & 131.2 & 142.8 & 152.8 & 156.2 \\
\hline Processing & 20.4 & 39.7 & 47.4 & 47.4 & 49.0 \\
\hline Supplies, including: & 109.3 & 119.8 & 128.8 & 137.9 & 141.7 \\
\hline -export & 16.3 & 34.2 & 38.4 & 42.0 & 47.3 \\
\hline -Russia's regions, of which & 93.0 & 89.1 & 90.4 & 95.9 & 94.4 \\
\hline - Coking demand & 0.1 & 1.9 & 2.6 & 2.6 & 2.7 \\
\hline - Power plants & 64.5 & 64.3 & 63.1 & 63.1 & 67.5 \\
\hline -Population and residential consumers & 13.7 & 11.5 & 12.2 & 12.2 & 13.1 \\
\hline -Other consumers & 14.7 & 11.4 & 12.6 & 12.6 & 12.6 \\
\hline
\end{tabular}

Source: [2]

Table 3. Coal reserves of the eastern regions of Russia by category of reserves as of January 1, 2019, billion $t$

\begin{tabular}{|c|c|c|c|c|}
\hline \multirow[t]{2}{*}{ Type of coal } & \multicolumn{3}{|c|}{ Balance reserves by category } & \multirow{2}{*}{$\begin{array}{c}\text { Non-commercial } \\
\text { reserves }\end{array}$} \\
\hline & $\mathrm{A}+\mathrm{B}+\mathrm{C} 1$ & $\mathrm{C} 2$ & $\mathrm{~A}+\mathrm{B}+\mathrm{C} 1+\mathrm{C} 2$ & \\
\hline Total, including & 88.0 & 39.9 & 127.8 & 29.2 \\
\hline - $\quad$ brown (lignite) & 61.2 & 25.4 & 86.6 & 12.0 \\
\hline hard & 26.7 & 14.4 & 41.2 & 17.1 \\
\hline of which coking & 8.9 & 4.5 & 13.4 & 1.4 \\
\hline including highly valuable ranks & 4.3 & 2.7 & 7.1 & 0.1 \\
\hline Anthracite & 0.03 & 0.03 & 0.07 & 0.07 \\
\hline Surface mining, including & 71.7 & 28.5 & 100.1 & 16.0 \\
\hline - $\quad$ brown (lignite) & 57.8 & 22.5 & 80.3 & 10.4 \\
\hline hard & 13.9 & 6.0 & 19.8 & 5.6 \\
\hline of which coking & 2.1 & 0.4 & 2.5 & 0.1 \\
\hline including highly valuable ranks & 1.4 & 0.3 & 1.8 & 0.0 \\
\hline Anthracite & 0.02 & 0.01 & 0.03 & 0.02 \\
\hline
\end{tabular}

Source: [3] 
Table 4. Projection of coal production in the eastern regions of Russia, million $t$ /year.

\begin{tabular}{|c|c|c|c|}
\hline \multirow[t]{3}{*}{ Federation entity } & \multicolumn{3}{|c|}{ Year } \\
\hline & 2019 & 2030 & 2035 \\
\hline & actual & & \\
\hline Total, including & 160.5 & $185-227$ & $195-271$ \\
\hline Krasnoyarsk Territory & 42.7 & $43-50$ & $39-50$ \\
\hline Republic of Khakassia & 27.1 & $35-41$ & $37-45$ \\
\hline Trans-Baikal Territory & 23.9 & $27-30$ & $27-36$ \\
\hline Republic of Sakha (Yakutia) & 18.6 & $24-31$ & $29-35$ \\
\hline Irkutsk Region & 13.1 & $11-12$ & $11-13$ \\
\hline Sakhalin Region & 12.9 & $14-15$ & 14-19 \\
\hline Primorye Territory & 7.9 & $9-10$ & $9-11$ \\
\hline Khabarovsk Territory & 6.3 & $10-13$ & $12-16$ \\
\hline Amur Region & 1.7 & $2-8$ & $6-15$ \\
\hline Republic of Tyva & 3.4 & $4-4$ & $4-8$ \\
\hline Kamchatka Territory & 0.0 & $1-3$ & $1-8$ \\
\hline Chukotka Autonomous Area & 0.0 & $1-4$ & $2-8$ \\
\hline Other & 2.9 & $4-6$ & $4-7$ \\
\hline
\end{tabular}

Source: Authors' estimates

Table 5. Projection of coal export from the eastern regions of Russia, million $t / y e a r$

\begin{tabular}{|c|c|c|c|}
\hline \multirow[t]{3}{*}{ Federation entity } & \multicolumn{3}{|c|}{ Year } \\
\hline & 2019 & 2030 & 2035 \\
\hline & actual & \multicolumn{2}{|c|}{ forecast } \\
\hline Total, including & 47.13 & $64-95$ & $74-129$ \\
\hline Republic of Khakassia & 11.27 & $17-22$ & $17-25$ \\
\hline Sakhalin Region & 11.78 & $12-13$ & $12-13$ \\
\hline Trans-Baikal Territory & 8.51 & $10-13$ & $12-15$ \\
\hline Republic of Sakha (Yakutia) & 8.64 & $12-17$ & $16-22$ \\
\hline Khabarovsk Territory & 3.28 & $6-9$ & $6-11$ \\
\hline Krasnoyarsk Territory & 1.1 & $2-4$ & $2-8$ \\
\hline Republic of Tyva & 0.1 & $1-6$ & $2-11$ \\
\hline Amur Region & 0 & $0-2$ & $2-6$ \\
\hline Kamchatka Territory & 0 & $1-2$ & $1-6$ \\
\hline Chukotka Autonomous Area & 0 & $1-3$ & $1-6$ \\
\hline Other & 2.45 & $2-4$ & $3-6$ \\
\hline
\end{tabular}

Source: Authors' estimates

considerable coal resources and production capacities in the eastern regions allow us to consider coal as a reliable resource to meet the demand of domestic consumers and to supply it for export.

\section{POTENTIAL FOR COAL PRODUCTION GROWTH}

The new and existing program documents of different levels include projects for the exploitation of new deposits, reconstruction, and expansion of the capacity of operating enterprises. At the same time, some existing enterprises use $50-90 \%$ of their production capacity. The projects address different coal utilization areas, first of all, its export, then the construction of coal-fired power plants, and the development of coal chemistry in the future. In recent years, the projects have been worked out for mining the deposits in the northern and north-eastern areas that are the most vulnerable from the environmental viewpoint but possess the reserves of coal demanded in the world market. Foreign companies are much interested in developing some of the deposits.

As for the international coal market, a coal demand projection made by international organizations is favorable for the intensive development of coal export from Russia's eastern regions to the potential coal importers [4]. The main coal competitors of Russia are Australia, Indonesia, and Mongolia in the future.
Construction of large coal-fired power plants in East Siberia and the Far East to meet the internal demand and to export electric power was considered in different Governmental [5-7], federal and regional strategies and programs. According to the documents, the plans were to construct coal-fired power plants on the run-of-mine coal and low-grade products of processing the coking and steaming coal.

Practically all brown and low-grade hard coals can be used in coal chemistry. The existing projects for the development of the coal chemical industry are at different stages of progress: from tentative estimation to specific steps of implementation. In the nearest future, coal supplies for coal chemistry will not essentially influence the coal production volumes.

According to the new projects, the production volumes for different deposits amount from 0.4 to $45 \mathrm{~m} \mathrm{t}$ /year, and to $355 \mathrm{~m} \mathrm{t}$ for the eastern regions as a whole. With the reconstruction and increase in the capacity of operating enterprises, coal production can reach up to $75 \mathrm{~m} \mathrm{t}$ /year.

The dates of project implementation depend on various factors, the most important of which are the state (often absence) of the transport infrastructure, availability of investment, demand for products, distance from the trade markets, and competition with other energy carriers. The 
run-of-mine coal is produced basically for the internal market, its processing products (concentrates of steaming and coking coal) are intended for the world market, and the low-grade processing products should be used to satisfy the needs of the energy sector.

The coals of the eastern regions contain some valuable associated components [8-10]. Owing to the high sorption properties of coal, a considerable amount of different metals and rare-earth elements remained in it in the process of deposit formation. This is how the complex deposits (uranium-coal, germanium-coal, rare-earth-coal ones) appeared, which creates the preconditions for complex utilization of coal deposits.

\section{FACTORS INFLUENCING THE TRENDS IN COAL INDUSTRY DEVELOPMENT OF THE EASTERN REGIONS OF RUSSIA}

The analysis of trends in the coal industry development of the eastern regions of Russia revealed the following main favorable factors for coal production increase:

- availability of considerable coal reserves, including the coal highly-demanded in the world market, which is suitable for different uses: export, energy sector, byproduct coke industry, coal chemistry;

- measures included in the program of coal industry development and other documents, such as the arrangement of interaction between science and industry, strengthening of the science-and-technology framework of coal companies and branch scientific centers; improvement in the transport infrastructure, including the port infrastructure, for development of coal export; development of coal-based energy sector using the advanced technologies of coal combustion; and others;

- location of coal deposits of the eastern regions promising for export development close to the world's key coal importers, namely the APR countries;

- the mid-term and long-term forecasts show the dynamics of the world coal consumption growth, mainly owing to the APR countries

The coal industry development of the eastern regions is hampered by the following factors:

- economic consequences of coronavirus pandemic in the world;

- deceleration of activity in the world coal markets;

- the fluctuation of the demand for and prices of coal in the world coal market;

- a lag between the development of the railway transport capacities and required shipping capabilities;

- environmental constraints on the development of the coal-based energy sector.

\section{PROSPECTS FOR THE DEVELOPMENT OF COAL PRODUCTION AND SUPPLY}

The coal industry development in the eastern regions of Russia and potential coal supply for export were projected for the entities of the eastern regions of Russia according to the economy and energy development scenarios, which were developed at MESI SB RAS [11,12], and the authors' estimates based on the existing trends in coal consumption and the analysis of program documents (Tables 4 and 5). The rise in the coal supply for export also depends on the increase in coal processing. The study relies on the software developed with the authors' participation $[13,14]$.

Table 4. Projection of coal production in the eastern regions of Russia, million $\mathrm{t} /$ year.

Source: Authors' estimates

Table 5. Projection of coal export from the eastern regions of Russia, million $\mathrm{t} /$ year

Source: Authors' estimates

\section{CONCLUSION}

The main trends in coal industry development are related to the growing export component in coal production. Therefore, the coal industry in the regions depends on the demand for coal and the price fluctuations in the world coal market. Foreign companies are interested in the exploitation of some deposits. Coal production expansion at these deposits depends both on the extent to which these companies participate in the projects and on the stability of their interests.

The prospects for coal export development also depend on the potential expansion of the internal and external coal markets; geopolitical conditions that limit coal consumption, and opportunities to increase the geological exploration. Despite the existing demand for coal, the growth of its export can be limited by the capabilities of transport infrastructure, the tariffs of coal shipping, and the absence of demand for low-grade products of coal processing in the internal market.

The creation of industrial clusters based on coal deposits (which will combine production enterprises for processing coal and technology-related waste; energy facilities; coal chemical enterprises and enterprises providing reclamation and other measures aimed at decreasing the environmental damage) appears to be the most effective alternative for the economy and environment. The run-of-mine coal, lowgrade beneficiation products, and gas from the coal seams can be used as fuel for energy facilities. The end products of coal chemical enterprises are the products with a high valueadded, which are produced in coal processing, degassing of coal seams, mine water, slag, and emissions into the air after coal combustion at power plants. Associated valuable elements in coal can be extracted by effective technologies and the introduction of clean combustion technologies. Since coal deposits are unique in their quality and other characteristics and conditions of deposit exploitation, such projects should be implemented approaching each deposit individually.

\section{REFERENCES}

[1] BP Statistical Review of World Energy June 2019 [Online]. Available: http://www.bp.com/ statisticalreview. (Accessed: December 23, 2020)

[2] Statistical data of FSBI "CDU TEK" [Online]. Available: https://www.cdu.ru/catalog/statistic/?arrFi 1ter_46_4252452532. (in Russian) 
[3] The state balance of reserves of mineral resources of the Russian Federation as of January 1, 2019. Issue 91, Coal, I, Summary data. - M.: Ministry of Natural Resources and Environment of the Russian Federation, Federal Agency on Mineral Management, the Russian Federal Geological Foundation, 302 p. (2019). (in Russian)

[4] BP Energy Outlook. 125 p. [Online]. Available: https://www.bp.com/content/dam/bp/en/corporate/ pdf/energy-economics/energy-outlook/bp-energyoutlook-2018.pdf. (2018). (Accessed: December 23, 2020). (in Russian)

[5] Scenario conditions of electric power industry development of Russia for the period until 2030. M.: Ministry of Energy, APBE,-202 p. (2011). (in Russian)

[6] The scheme of territorial planning of the RF applicable to the energy sector until 2030. [Online]. Available: http://docs.cntd.ru/document/420369441. Accessed: December 23, 2020). (in Russian)

[7] The strategy of socio-economic development of the Far East and the Baikal region until 2025. [Online]. Available: http://docs.cntd.ru/document/902195483. (Accessed: December 23, 2020). (in Russian)

[8] Arbuzov S.I., Mashenkin V.S., Rybalko V.I., Sudyko A.F. The rare-metal potential of coals of Northern Asia (Siberia, the Russian Far East, Kazakhstan, Mongolia). Geology and mineral re-sources of Siberia. No.3, p.4144. (2014). (in Russian)

[9] Lavrik N. A. Some prerequisites for complex mining of coal deposits in the south of the Far East // Mountain information-analytical bulletin. Individual issue: «The Far East» P. 420-430. (2005). (in Russian)

[10] Golitsyn M.V., Vyalov V.I., Bogomolov A.H., Pronina N.V., Makarova E.Yu., Mitronov D.V., Kuzevanova E.V., Makarov D.V. Prospects for the development of technological coal use in Rus-sia. Georesources. No. 2(61). P. 41-53. (2015). (in Russian)

[11] Lagerev A.V., Khanaeva V.N. Priorities in the energy sector development in the Asian regions of Russia in the long-term future // Spatial economy. No. 3. P. 154-166. DOI: 10.14530/se.2017.3.154-166 (2017). (in Russian)

[12] Smirnov K.S. Complex estimation of implementing the projects on the Russian electric power ex-port from East Siberia to China // Bulletin of Irkutsk State Technical University. 2017. V. 21. No. 10. P. 131-137. DOI: 10.21285/1814-3520-2017-10-131-13. (in Russian)

[13] Sokolov A.D., Takaishvili L.N. Information and modeling software for planning the expansion of coal systems based on the hierarchical approach / in Hierarchical modeling of energy systems (Novosibirsk. Academic Publishing House "GEO," 2020. p. 209212.). (in Russian)

[14] Sokolov A.D., Takaishvili L.N. Implementation of the software to forecast coal industry devel-opment in Russia's regions. State-of-the-art technologies. System analysis. Modeling. No. 1(41), pp. 126-133. (2014). (in Russian)

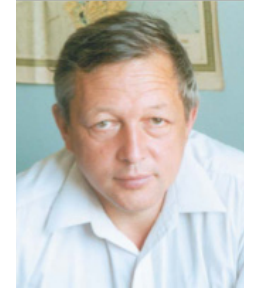

Alexander Sokolov received D. Sc. degree in engineering from the Melentiev Energy Systems Institute of the Siberian Branch of the Russian Academy of Sciences in 2006. Currently, he is a chief researcher and the head of the Laboratory of the Energy Sector of Siberia and the Far East at the Melentiev Energy Systems Institute SB RAS. His research interests include the studies and modeling of the development prospects of the energy sector industries.

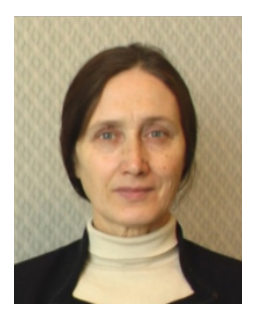

Liudmila Takaishvili received a Ph.D. in engineering from the Melentiev Energy Systems Institute of the Siberian Branch of the Russian Academy of Sciences in 1991. Currently, she is a senior researcher at the Melentiev Energy Systems Institute SB RAS. Her research areas include the studies of the coal industry development prospects and the development of software and information support for these studies. 